\title{
IMPACT OF AGRICULTURAL WASTE RETURN ON SOIL GREENHOUSE GAS EMISSIONS
}

\author{
HuANG, D. D. ${ }^{1,2}-$ CAO, G. J. ${ }^{1 *}$-GENG, Y. H. ${ }^{1}$ - WANG, L. C. ${ }^{3 *}-$ CHEN, X. W. ${ }^{2,4}-$ LiANG, A. Z. ${ }^{2,4}$ \\ ${ }^{1}$ College of Resource and Environment, Jilin Agricultural University \\ Changchun 130118, China
}

${ }^{2}$ Key Laboratory of Mollisols Agroecology, Northeast Institute of Geography and Agroecology Chinese Academy of Sciences, Changchun 130102, China

${ }^{3}$ Institute of Agricultural Resource and Environment, Jilin Academy of Agricultural Sciences Changchun 130033, China

${ }^{4}$ University of Chinese Academy of Sciences, Beijing 100049, China

*Corresponding authors

e-mail: cgj72@126.com (Cao, G.J.); wlc1960@163.com(Wang, L. C.)

(Received $12^{\text {th }}$ Oct 2018; accepted 20 $0^{\text {th }}$ Dec 2018)

\begin{abstract}
The effects of agricultural waste return on the emissions of greenhouse gases $\left(\mathrm{CO}_{2}, \mathrm{~N}_{2} \mathrm{O}\right.$ and $\mathrm{CH}_{4}$ ) from corn farmland in the black soil region of Northeast China and its potential to increase temperature were studied to provide a theoretical basis for formulating reduction measures of agricultural greenhouse gas emissions. This study was conducted at the Experimental Station of China Agricultural University in Quanyangou, Lishu County, Siping City, Jilin Province. Static greenhouse gas chromatography was used to monitor soil greenhouse gas fluxes under different fertilization measures, and the different fertilization treatments were analyzed for comprehensive differences in greenhouse effects among corn fields. The results showed that the average $\mathrm{CO}_{2}$ fluxes and total emissions in response to the straw return treatment were the highest, reaching $388.96 \mathrm{mg} \cdot \mathrm{m}^{-2} \cdot \mathrm{h}^{-1}$ and $14718.97 \mathrm{~kg} \cdot \mathrm{hm}^{-2}$, respectively, and nitrogen topdressing fertilizer significantly increased $\mathrm{CO}_{2}$ emissions. With respect to $\mathrm{CH}_{4}$ emissions, single fertilizer-treated plots had the highest average absorbed flux and total absorption$0.042 \mathrm{mg} \cdot \mathrm{m}^{-2} \cdot \mathrm{h}^{-1}$ and $1.36 \mathrm{~kg} \cdot \mathrm{hm}^{-2}$, respectively, and with respect to $\mathrm{N}_{2} \mathrm{O}$ fluxes, the highest flux and amount were $0.153 \mathrm{mg} \cdot \mathrm{m}^{-2} \cdot \mathrm{h}^{-1}$ and $5.75 \mathrm{~kg} \cdot \mathrm{hm}^{-2}$, respectively. The global warming potential of the straw in situ treatment was significantly higher than that of the other treatments, and the global warming potential of the cattle manure treatment was lower than that of the single chemical fertilizer treatment, but the differences were not significant. Moreover, straw mulch increased $\mathrm{CO}_{2}$ emissions from black soils, and dry soils were shown to be important sinks of atmospheric $\mathrm{CH}_{4}$. Combinations of organic and inorganic fertilizers and individual fertilizers can reduce $\mathrm{N}_{2} \mathrm{O}$ emissions from soils. Therefore, to achieve higher corn yields and to reduce greenhouse gas emission intensities simultaneously, applications of organic and inorganic fertilizers constitute an ideal soil fertility method in the black soil region of Northeast China.
\end{abstract}

Keywords: $\mathrm{CO}_{2}, \mathrm{~N}_{2} \mathrm{O}, \mathrm{CH}_{4}$, global warming potential, emission intensity

\section{Introduction}

With the increasing attention of the international community on climate change, food security and reduced greenhouse gas emissions, research on grain production and reducing greenhouse gas emissions from farmlands has received unprecedented attention from the scientific community (Intergovernmental Panel on Climate Change, 2013). It is estimated that $\mathrm{CO}_{2}, \mathrm{CH}_{4}$ and $\mathrm{N}_{2} \mathrm{O}$ emissions from agriculture account for approximately $12 \%, 50 \%$, and $60 \%$ of the global anthropogenic greenhouse gas emissions, respectively (Ge et al., 2014). The contribution of these three major 
greenhouse gases combined to global warming has been reported to be as high as $80 \%$ (Yuan et al., 2017). Agricultural activities are one of the major sources of greenhouse gas emissions (Yue et al., 2017). Among them, $\mathrm{CH}_{4}$ emissions from animal manure have reached $2.86 \times 10^{6} \mathrm{t}$, and $\mathrm{N}_{2} \mathrm{O}$ emissions from animal manure have reached $2.66 \times 10^{5} \mathrm{t}$, accounting for $28.35 \%$ of the total $\mathrm{N}_{2} \mathrm{O}$ emissions from agricultural activities; moreover, $\mathrm{N}_{2} \mathrm{O}$ emissions from compost account for $5.2 \%$ of the $\mathrm{N}_{2} \mathrm{O}$ emissions animal manure (National Development and Reform Commission, 2013). Agricultural soils contribute greatly to greenhouse gas emissions (Krobel et al., 2016; Zhang et al., 2017). Fertilization of agricultural soils has a crucial influence on soil greenhouse gas emissions (Cheng et al., 2016; Zhang et al., 2012). Agricultural management techniques such as planting patterns, farming practices, grain filling, and stubble application strongly affect agricultural greenhouse gas emissions. Among all these techniques, fertilization has the greatest impact on greenhouse gas emissions (Qin et al., 2016; Salehi et al., 2017; Zhang et al., 2016a). With the gradual increase in worldwide population, the demand for food will increase, and the amount of greenhouse gas emissions from excessive agricultural activities (such as fertilization) will increase. Thus, the contradiction between food security and greenhouse gas emissions will need to be eliminated; that is, under the premise of ensuring food security, the effective reduction in farmland greenhouse gas emissions will be needed, which is a major problem for the sustainable development of agriculture.

China currently produces the largest agricultural waste output worldwide. The amount of crop straw produced is approximately 650 million tons, and the amount of livestock and poultry manure is approximately 1.73 billion tons (Lozano et al., 2017; $\mathrm{Xu}$ et al., 2018; Zhao et al., 2016). These agricultural wastes are not being properly used, which has resulted in a waste of resources and has caused a severe threat to the environment. Researchers in China and abroad have reported that the return of agricultural waste to the field can not only reduce resource waste, reduce the application of chemical fertilizers, improve soil structure, increase soil fertility, and reduce environmental pollution but also affect greenhouse gas emissions by altering soil carbon (C) sequestration potential, which then slows the contribution to global climate change (Epps et al., 2016; Mitran et al., 2016; Zhang et al., 2016). Therefore, replacing some chemical fertilizers with organic fertilizers is an inevitable trend concerning fertilizer applications in the future in China (Ding et al., 2016). This experiment takes corn farmland on black soil in the central part of Jilin Province as a research object and adopts the static box method to study how applications of cow manure, chicken manure, straw and chemical fertilizer under conditions of high organic fertilizer substitution, as well as nitrogen $(\mathrm{N})$, phosphorus $(\mathrm{P})$, potassium $(\mathrm{K})$ and other nutrients, impact greenhouse gas emissions and the warming potential of those emissions. The purpose of this study is to provide a theoretical basis for the resource utilization of agricultural waste and a scientific evaluation of its role in greenhouse gas emissions.

\section{Material and methods}

\section{Study site}

This experiment was conducted at the Experimental Station of China Agricultural University in Quanyangou, Lishu County, Siping City, Jilin Province, in 2014. The location of the sampling site is given in Figure 1. The area had been used to grow monoculture corn under conventional management for more than 10 years, which is 
harvested annually, and the soil at the site is black soil. The annual average temperature is $6.5^{\circ} \mathrm{C}$, the sunshine duration is $2393-2928 \mathrm{~h} \cdot$ year $^{-1}$, the frost-free period is $115-188$ days, and the annual cumulative temperature $>10^{\circ} \mathrm{C}$ is $2900-3100^{\circ} \mathrm{C}$. The average annual rainfall is $577 \mathrm{~mm}$ and is concentrated mainly in June-August, accounting for approximately $65 \%$ of the annual precipitation, and the average annual evaporation is $790-820 \mathrm{~mm}$. The basic physical and chemical properties of the $0-20 \mathrm{~cm}$ soil layer are as follows: $\mathrm{pH}$ of $6.69,19.90 \mathrm{~g} \cdot \mathrm{kg}^{-1}$ organic matter, $1.26 \mathrm{~g} \cdot \mathrm{kg}^{-1}$ total $\mathrm{N}, 90.72 \mathrm{mg} \cdot \mathrm{kg}^{-1}$ alkaline hydrolysis $\mathrm{N}, 21.27 \mathrm{mg} \cdot \mathrm{kg}^{-1}$ available $\mathrm{P}$, and $186.18 \mathrm{mg} \cdot \mathrm{kg}^{-1}$ available $\mathrm{K}$.

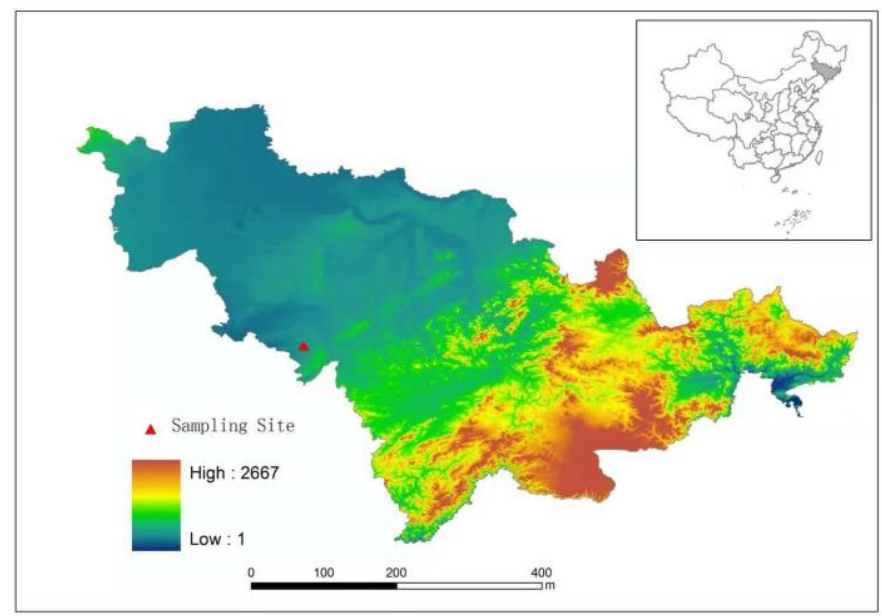

Figure 1. Sampling site

\section{Experimental material}

The tested corn variety Liangyu 11 was planted at a ridge spacing of $60 \mathrm{~cm}$, a density of 65000 plants $\cdot \mathrm{ha}^{-1}$ and an intended plant spacing of $25.6 \mathrm{~cm}$. With respect to the tested inorganic fertilizers, $\mathrm{N}$ was supplied as urea $(46 \% \mathrm{~N}), \mathrm{P}$ was supplied as diammonium phosphate $\left(18 \% \mathrm{~N}, 46 \% \mathrm{P}_{2} \mathrm{O}_{5}\right)$ or heavy superphosphate $\left(46 \% \mathrm{P}_{2} \mathrm{O}_{5}\right)$, and $\mathrm{K}$ was supplied potassium sulfate $\left(\mathrm{K}_{2} \mathrm{O} 50 \%\right)$, and agricultural waste included cow manure, chicken manure and corn stalks. The nutrient contents of the different agricultural wastes are shown in Table 1.

Table 1. Nutrient contents of different agricultural wastes (w/\%)

\begin{tabular}{c|c|c|c|c}
\hline Organic material & Organic matter & Nitrogen & Phosphorus & Potassium \\
\hline Cow manure & 30.34 & 1.5 & 0.96 & 1.23 \\
Chicken manure & 34.38 & 2.87 & 1.56 & 1.68 \\
Corn stalks & 58.9 & 0.72 & 0.25 & 1.5 \\
\hline
\end{tabular}

\section{Experimental design}

The experiment consisted of 5 treatments, 5 test plots, 3 gas collection boxes placed in each treatment plot, and 3 replicates. Each plot was $76 \mathrm{~m}^{2}$, and the area received natural rainfall and no artificial irrigation. This experiment adopts the principle of equal $\mathrm{N}, \mathrm{P}$, and $\mathrm{K}$ nutrient contents for the experimental design. The $\mathrm{N}, \mathrm{P}$, and $\mathrm{K}$ contents in the agricultural waste were converted to pure $\mathrm{N}$, pure $\mathrm{P}$, and pure $\mathrm{K}$ for analysis. To 
generate straw for returning to the field, plants were planted at a density of 65000 plants $\cdot \mathrm{hm}^{-2}$. One hundred percent of the straw produced was returned to the field, and cow manure and chicken manure were applied to the field at $50 \%$ of the total $\mathrm{N}$ application rate $\left(240 \mathrm{~kg} \cdot \mathrm{hm}^{-2}\right)$. The remaining amounts of $\mathrm{N}, \mathrm{P}$, and $\mathrm{K}$ in the organic fertilizers remained in the treatments, and the nutrient content deficiencies were compensated with chemical fertilizers. In other words, it was ensured that the total N, P and $\mathrm{K}$ nutrient components applied to the soil in all fertilization treatments were equal, namely, $240 \mathrm{~kg} \cdot \mathrm{hm}^{-2}$ pure $\mathrm{N}, 100 \mathrm{~kg} \cdot \mathrm{hm}^{-2} \mathrm{P}_{2} \mathrm{O}_{5}$ and $120 \mathrm{~kg} \cdot \mathrm{hm}^{-2} \mathrm{~K}_{2} \mathrm{O}$. The nitrogen and phosphorus nutrients contained in the straw are insufficient, and the rest is supplemented by chemical fertilizer. The excess potassium in the straw does not need to be supplemented. The five treatments were: CK, no fertilization; S1: single chemical fertilizer application, $\mathrm{N} 240 \mathrm{~kg} \cdot \mathrm{hm}^{-2}, \mathrm{P}_{2} \mathrm{O}_{5} 100 \mathrm{~kg} \cdot \mathrm{hm}^{-2}, \mathrm{~K}_{2} \mathrm{O} 120 \mathrm{~kg} \cdot \mathrm{hm}^{-2}$; S2: straw totally returned to the field, fertilizer nitrogen accounted for nearly $90 \%$ of the nitrogen application rate. S3: cow manure returned to the field, the manure nitrogen and chemical fertilizer nitrogen both accounted for $50 \%$ of the nitrogen application rate; S4: chicken manure returned to the field, chicken nitrogen and fertilizer nitrogen both accounted for $50 \%$ of the nitrogen application rate.

Thirty percent of the $\mathrm{N}$ fertilizer application amount was supplied as a basal fertilizer, $40 \%$ was applied as topdressing, and 30\% was also applied as topdressing. The agricultural wastes as well as the $\mathrm{P}$ and potash fertilizers were applied as basal fertilizers at the same time. The specific fertilization schemes are listed in Table 2.

On April 27, the agricultural waste was applied to the test plots; it was evenly mixed with the soil to cover the ground surface. On April 28, after mechanical ridging, the surface soil covered the agricultural waste. Manual sowing was conducted on April 29, and the first gas collection was performed on April 30. Fertilization occurred on June 27 and July 28 at the jointing stage and tasseling stages, respectively.

Table 2. Experimental treatment and fertilizer amounts

\begin{tabular}{|c|c|c|c|c|c|c|c|c|}
\hline \multirow{2}{*}{\multicolumn{2}{|c|}{ Treatment }} & \multirow[b]{2}{*}{$\begin{array}{l}\text { Organic } \\
\text { Fertilizer } \\
\left(\mathbf{t} \cdot \mathbf{h m}^{-2}\right)\end{array}$} & \multicolumn{3}{|c|}{ Organic material $\left(\mathrm{kg} \cdot \mathrm{hm}^{-2}\right)$} & \multicolumn{3}{|c|}{ Fertilizer $\left(\mathrm{kg} \cdot \mathrm{hm}^{-2}\right)$} \\
\hline & & & $\begin{array}{l}\text { Amount } \\
\text { of } N\end{array}$ & $\begin{array}{l}\text { Amount } \\
\text { of } \mathrm{P}_{2} \mathrm{O}_{5}\end{array}$ & $\begin{array}{c}\text { Amount } \\
\text { of } \mathrm{K}_{2} \mathrm{O}\end{array}$ & $\begin{array}{c}\mathrm{N} \\
\text { application } \\
\text { rate }\end{array}$ & $\begin{array}{c}\mathbf{P}_{2} \mathrm{O}_{5} \\
\text { application } \\
\text { rate }\end{array}$ & $\begin{array}{c}\mathrm{K}_{2} \mathrm{O} \\
\text { application } \\
\text { rate }\end{array}$ \\
\hline CK & $\begin{array}{c}\text { No } \\
\text { fertilization }\end{array}$ & 0 & 0 & 0 & 0 & 0 & 0 & 0 \\
\hline $\mathrm{S} 1$ & Fertilizer & 0 & 0 & 0 & 0 & 240 & 100 & 120 \\
\hline $\mathrm{S} 2$ & $\begin{array}{l}\text { Straw return } \\
\text { Cow manure }\end{array}$ & 12.9 & 24.38 & 22.58 & 135.45 & 215.62 & 77.43 & 0 \\
\hline S3 & $\begin{array}{l}\text { applied to the } \\
\text { field }\end{array}$ & 26.67 & 120 & 76.8 & 98.4 & 120 & 23.2 & 21.6 \\
\hline S4 & $\begin{array}{c}\text { Chicken } \\
\text { manure } \\
\text { applied to the } \\
\text { field }\end{array}$ & 13.29 & 120 & 65.22 & 70.24 & 120 & 34.78 & 49.76 \\
\hline
\end{tabular}

\section{Gas sampling}

Greenhouse gas samples were collected using the static box method (Yuan et al., 2017). The gas collection box consisted of stainless steel plates welded together. When gas is collected, water is injected into the gas tank, forming a liquid seal with the gas box lid to ensure that the gas in the tank is closed. Gas samples were collected four times between 9:00 a.m. and 11:00 a.m. for 0, 15, 30, and $45 \mathrm{~min}$, after which $100 \mathrm{ml}$ of 
each sample was then pumped into a $100 \mathrm{ml}$ syringe. The sample was subsequently injected into a gas collection bag for storage, which was returned to the laboratory. The temperature inside the box, the soil temperature at a $5 \mathrm{~cm}$ depth, the atmospheric temperature, and the atmospheric pressure were recorded to correct the gas mass error caused by the increase in the temperature during the sampling process. The gas sample in the collection bag was ultimately injected into a designated vacuum flask as a sample of the greenhouse gas and sent to the Institute of Applied Ecology, Chinese Academy of Sciences, for testing. The experiment was started on April 29, and the plants were harvested on September 28. The whole growth period was 153 days. Because of the continuous use of basal fertilizers, samples were collected for 7 days, and the $\mathrm{N}$ fertilizer topdressings were applied on June 27 and July 28. After continuous sampling for 3 days, the remaining samples were collected once a week. However, due to the large amount of rainfall that occurred on the sample collection day, the gas could not be collected normally, and the gas collection time was delayed. Sampling was performed a total of 29 times. The specific sampling time is shown in Table 3.

Table 3. Date and number of sampling

\begin{tabular}{cc|cc|cc}
\hline Number & Date & Number & Date & Number & Date \\
\hline 1 & Apr.30 & 11 & Jun.4 & 21 & Jul.30 \\
2 & May.1 & 12 & Jun.12 & 22 & Jul.31 \\
3 & May.3 & 13 & Jun.19 & 23 & Aug.7 \\
4 & May.4 & 14 & Jun.28 & 24 & Aug.18 \\
5 & May.5 & 15 & Jun.29 & 25 & Aug.27 \\
6 & May.6 & 16 & Jun.30 & 26 & Sep.3 \\
7 & May.7 & 17 & Jul.7 & 27 & Sep.10 \\
8 & May.14 & 18 & Jul.14 & 28 & Sep.17 \\
9 & May.21 & 19 & Jul.22 & 29 & Sep.25 \\
10 & May.28 & 20 & Jul.29 & & \\
\hline
\end{tabular}

\section{Test items and methods}

Determination of greenhouse gases $\left(\mathrm{CO}_{2}, \mathrm{~N}_{2} \mathrm{O}, \mathrm{CH}_{4}\right)$ : Gas samples were collected from a static chamber, and the contents of the greenhouse gases were determined by gas chromatography. An Agilent gas chromatograph instrument 7890A (Agilent Technologies Co., Ltd, USA) was used, and the $\mathrm{CO}_{2}$ and $\mathrm{CH}_{4}$ were determined by a hydrogen flame detector (FID). $\mathrm{N}_{2} \mathrm{O}$ was determined using an electron capture detector (ECD). The measurement conditions were as follows: for the FID, the temperature was $300^{\circ} \mathrm{C}$, the $\mathrm{H} 2$ gas flow rate was $100 \mathrm{ml} \cdot \mathrm{min}^{-1}$, the practical air flow rate was 200 $\mathrm{ml} \cdot \min ^{-1}$, and the carrier gas was $\mathrm{N}_{2}$; for the $\mathrm{ECD}$, the temperature was $330^{\circ} \mathrm{C}$, and the carrier gas was $\mathrm{N}_{2}$ at a flow rate of $2 \mathrm{ml} \cdot \mathrm{min}^{-1}$.

The greenhouse gas emission flux was calculated as

$$
F=\rho \bullet \mathrm{h} \bullet \mathrm{dc} / \mathrm{dt} \bullet 273 /(273+\mathrm{T})
$$

where $\mathrm{F}$ is the greenhouse gas flux $\left(\mu \mathrm{g} \cdot \mathrm{m}^{-2} \cdot \mathrm{h}^{-1}\right) ; \rho$ is the density of $\mathrm{CO}_{2}, \mathrm{~N}_{2} \mathrm{O}$, or $\mathrm{CH}_{4}$ in the standard state $\left(\mathrm{kg} \cdot \mathrm{m}^{-3}\right) ; \mathrm{h}$ is the height of the sampling box $(\mathrm{m})$; dc/dt is the concentration of greenhouse gases in the sampling tank; and $\mathrm{T}$ is the average temperature $\left({ }^{\circ} \mathrm{C}\right)$ in the sampling chamber during sampling. 


\section{Data analysis}

Statistical analyses were carried out using SPSS (version 11.5, SPSS Inc., Chicago, IL, USA), and the treatment means were compared using the least significant difference (LSD) test at a significance level of $\mathrm{P}<0.05$ (Liang et al., 2016).

\section{Results}

\section{Atmospheric Temperature, Soil Temperature, and Rainfall During Greenhouse Gas Collection}

The environmental conditions on the gas sampling day during the corn growth period in 2014 is shown in Figure 2. From April 29 to September 28 (autumn), measurements were taken on a total of 153 days. The atmospheric temperature in the figure is the temperature from 9:00 a.m. to 11:00 a.m. on the collection day. The maximum temperature was $33.03^{\circ} \mathrm{C}$, the minimum temperature was $8.00^{\circ} \mathrm{C}$, and the average temperature was $22.33^{\circ} \mathrm{C}$. The $5 \mathrm{~cm}$ belowground temperature represents the mean ground temperature measured by the three gas collection boxes after gas collection on the sampling days; the maximum temperature was $25.33^{\circ} \mathrm{C}$, the minimum temperature was $6.23^{\circ} \mathrm{C}$, and the average temperature was $18.00^{\circ} \mathrm{C}$. During the growth period, the cumulative rainfall was $354.86 \mathrm{~mm}$, and the greatest daily rainfall amounts occurred on June 7 and August 25, which were $38.63 \mathrm{~mm}$ and $37.83 \mathrm{~mm}$, respectively.

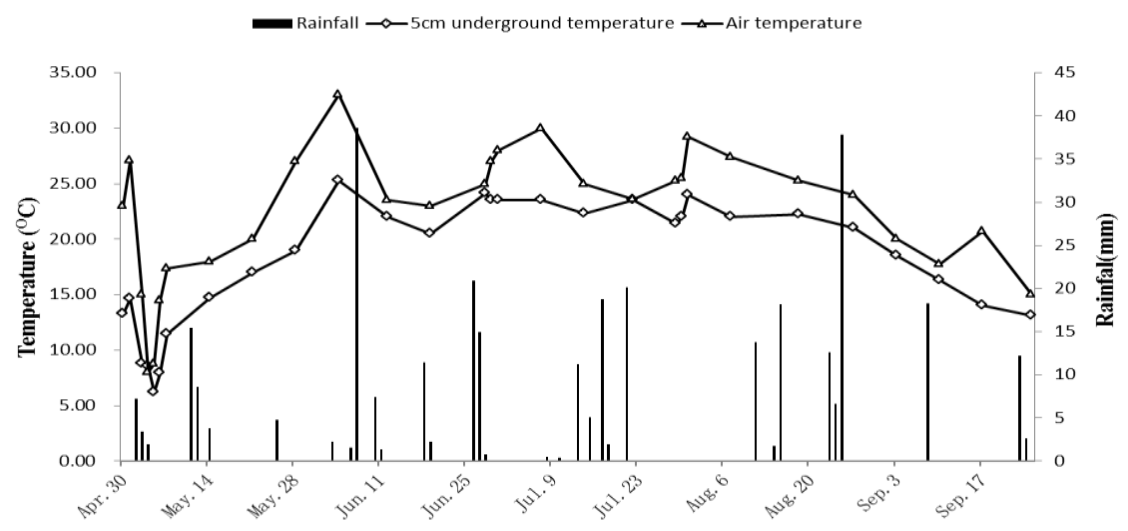

Figure 2. Variation in temperature and rainfall from April 28, 2014, to September 28, 2014

\section{Effects of Agricultural Waste on $\mathrm{CO}_{2}$ Emission Dynamics}

As shown in Figure 3, the $\mathrm{CO}_{2}$ emissions during the whole growth period of corn were essentially the same across all treatments and showed clear seasonal changes; that is, the $\mathrm{CO}_{2}$ emission flux at the beginning and end of the growth period was relatively low (39.9 to $\left.126.5 \mathrm{mg} \cdot \mathrm{m}^{-2} \cdot \mathrm{h}^{-1}\right)$. The medium-term emission flux was the highest and peaked at the end of June and at the end of July. Between May 28 and July 31, $\mathrm{CO}_{2}$ emissions in the control (CK) treatment exceeded $200.00 \mathrm{mg} \cdot \mathrm{m}^{-2} \cdot \mathrm{h}^{-1}$ and accounted for $81.64 \%$ of the total $\mathrm{CO}_{2}$ emissions during the entire growth period. After each fertilization treatment, the $\mathrm{CO}_{2}$ emissions increased. Under conditions of equal nutrient concentrations, the average $\mathrm{CO}_{2}$ flux in each treatment was greater than $200 \mathrm{mg} \cdot \mathrm{m}^{-2} \cdot \mathrm{h}^{-1}$. Excluding the $\mathrm{CK}$ treatment, the other treatments each presented two peaks of $\mathrm{CO}_{2}$ 
emissions after $\mathrm{N}$ fertilizer was topdressed at the end of June and at the end of July. As shown in Table 4, the greatest difference between the average $\mathrm{CO}_{2}$ emission flux and the total emissions in each treatment was significant, and the average emission flux and total emissions of $\mathrm{CO}_{2}$ in the straw return treatment (S2) were the highest among the treatments, $0.77 \%$ higher $(\mathrm{P}<0.05)$ than $\mathrm{S} 1,8.95 \%$ higher $(\mathrm{P}<0.05)$ than $\mathrm{S} 3,3.76 \%$ higher $(\mathrm{P}<0.05)$ than $\mathrm{S} 4$. With the exception of those in the $\mathrm{CK}$ treatment, the cumulative $\mathrm{CO}_{2}$ emissions in the cow manure treatment were the lowest, $3.07 \%$ lower $(\mathrm{P}<0.05)$ than $\mathrm{S} 1,9.43 \%$ lower $(\mathrm{P}<0.05)$ than $\mathrm{S} 2$, and $4.49 \%$ lower $(\mathrm{P}<0.05)$ than $\mathrm{S} 4$.

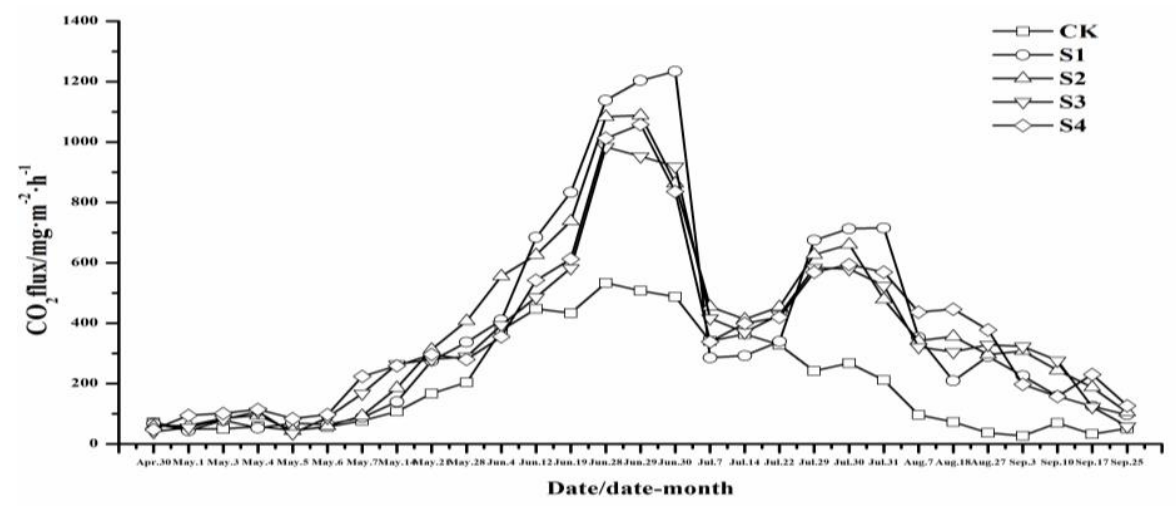

Figure 3. Emission flux of $\mathrm{CO}_{2}$ under conditions of agricultural waste returned to the field

Table 4. Average emission flux and total cumulative emissions of $\mathrm{CO}_{2}, \mathrm{~N}_{2} \mathrm{O}$ and $\mathrm{CH}_{4}$

\begin{tabular}{|c|c|c|c|}
\hline & Treatment & Average emission flux $\left(\mathrm{mg} \cdot \mathrm{m}^{-2} \cdot \mathrm{h}^{-1}\right)$ & Cumulative emission flux $\left(\mathrm{kg} \cdot \mathrm{hm}^{-2}\right)$ \\
\hline \multirow{5}{*}{$\mathrm{CO}_{2}$} & CK & $200.20 d$ & $7538.85 \mathrm{e}$ \\
\hline & $\mathrm{S} 1$ & $385.97 b$ & $13753.68 \mathrm{c}$ \\
\hline & S2 & $388.96 \mathrm{a}$ & $14718.97 \mathrm{a}$ \\
\hline & S3 & $357.02 \mathrm{c}$ & $13330.94 d$ \\
\hline & $\mathrm{S} 4$ & $374.83 \mathrm{~b}$ & $13957.28 b$ \\
\hline \multirow{5}{*}{$\mathrm{N}_{2} \mathrm{O}$} & $\mathrm{CK}$ & $0.049 \mathrm{c}$ & $2.07 \mathrm{c}$ \\
\hline & $\mathrm{S} 1$ & $0.153 \mathrm{a}$ & $5.75 \mathrm{a}$ \\
\hline & S2 & $0.139 b$ & $5.51 b$ \\
\hline & S3 & $0.137 b$ & $5.35 b$ \\
\hline & S4 & $0.136 \mathrm{~b}$ & $5.21 \mathrm{~b}$ \\
\hline \multirow{5}{*}{$\mathrm{CH}_{4}$} & $\mathrm{CK}$ & $-0.035 \mathrm{ab}$ & $-1.32 \mathrm{ab}$ \\
\hline & $\mathrm{S} 1$ & $-0.042 \mathrm{a}$ & $-1.36 \mathrm{a}$ \\
\hline & S2 & $-0.025 b$ & $-0.81 \mathrm{~d}$ \\
\hline & S3 & $-0.030 \mathrm{~b}$ & $-1.05 \mathrm{c}$ \\
\hline & S4 & $-0.034 \mathrm{ab}$ & $-1.23 b$ \\
\hline
\end{tabular}

Values followed by the same letter within a column indicate no significant difference at 0.05 level for $\mathrm{CO}_{2}, \mathrm{~N}_{2} \mathrm{O}$ and $\mathrm{CH}_{4}$

\section{Effects of Agricultural Waste on the Dynamic Characteristics of $\mathrm{N}_{2} \mathrm{O}$ Emissions}

The $\mathrm{N}_{2} \mathrm{O}$ flux from the farmland during the corn growth period is shown in Figure 4. All treatments presented positive values, indicating that dryland soil is a source of $\mathrm{N}_{2} \mathrm{O}$ emissions. The figure shows that, in the $\mathrm{CK}$ treatment, the $\mathrm{N}_{2} \mathrm{O}$ fluctuated widely, ranging from $5.43 \mu \mathrm{g} \cdot \mathrm{m}^{-2} \cdot \mathrm{h}^{-1}$ to $116.10 \mu \mathrm{g} \cdot \mathrm{m}^{-2} \cdot \mathrm{h}^{-1}$; moreover, the $\mathrm{N}_{2} \mathrm{O}$ emissions peaked at $95.38 \mu \mathrm{g} \cdot \mathrm{m}^{-2} \cdot \mathrm{h}^{-1}, 116.10 \mu \mathrm{g} \cdot \mathrm{m}^{-2} \cdot \mathrm{h}^{-1}$ and $97.17 \mu \mathrm{g} \cdot \mathrm{m}^{-2} \cdot \mathrm{h}^{-1}$ on June 26 , July 21 and 
August 25, respectively, which may be related to the occurrence of relatively large amounts of rainfall. From June 12 to August 27, the $\mathrm{N}_{2} \mathrm{O}$ emissions in the CK treatment exceeded $50.00 \mu \mathrm{g} \cdot \mathrm{m}^{-2} \cdot \mathrm{h}^{-1}$, and the average $\mathrm{N}_{2} \mathrm{O}$ emission flux in the CK treatment was $49.32 \mu \mathrm{g} \cdot \mathrm{m}^{-2} \cdot \mathrm{h}^{-1}$. During the whole growth period, the $\mathrm{N}_{2} \mathrm{O}$ emission flux in each fertilizer treatment ranged from $11.90 \mu \mathrm{g} \cdot \mathrm{m}^{-2} \cdot \mathrm{h}^{-1}$ to $374.72 \mu \mathrm{g} \cdot \mathrm{m}^{-2} \cdot \mathrm{h}^{-1}$. Under conditions of equal $\mathrm{N}, \mathrm{P}$ and $\mathrm{K}$ nutrient contents, the maximum $\mathrm{N}_{2} \mathrm{O}$ emissions $\left(374.72 \mu \mathrm{g} \cdot \mathrm{m}^{-2} \cdot \mathrm{h}^{-1}\right)$ occurred on June 29 in response to a single application of chemical fertilizer (S1 treatment), most likely due to rainfall that occurred on June 26 and June 27. With respect to the topdressing results, the single fertilizer application (S1) treatment also presented $\mathrm{N}_{2} \mathrm{O}$ emission peaks on June 12 and July 30, which may be related to rainfall events that occurred on June 10 and fertilizer applied on July 28. As shown in Table 4, the average $\mathrm{N}_{2} \mathrm{O}$ emission flux and total emissions between the agricultural waste treatments followed the order of $\mathrm{S} 1>\mathrm{S} 2>\mathrm{S} 3>\mathrm{S} 4$, the average emission flux of $\mathrm{S} 1$ treatment $\mathrm{N}_{2} \mathrm{O}$ is $10.07 \%, 11.68 \%, 12.5 \%$ higher $(\mathrm{P}<0.05)$ than $\mathrm{S} 2, \mathrm{~S} 3$ and $\mathrm{S} 4$, respectively, the difference between $\mathrm{S} 2, \mathrm{~S} 3$ and $\mathrm{S} 4$ was not significant; however, the total emissions in S2, S3 and S4 significantly differed from those in S1, and the average $\mathrm{N}_{2} \mathrm{O}$ emissions were the highest in the $\mathrm{S} 1$ treatment, the cumulative emissions of $\mathrm{S} 1$ treatment are $4.35 \%, 7.48 \%, 10.36 \%$ higher $(\mathrm{P}<0.05)$ than $\mathrm{S} 2, \mathrm{~S} 3$ and $\mathrm{S} 4$, respectively.

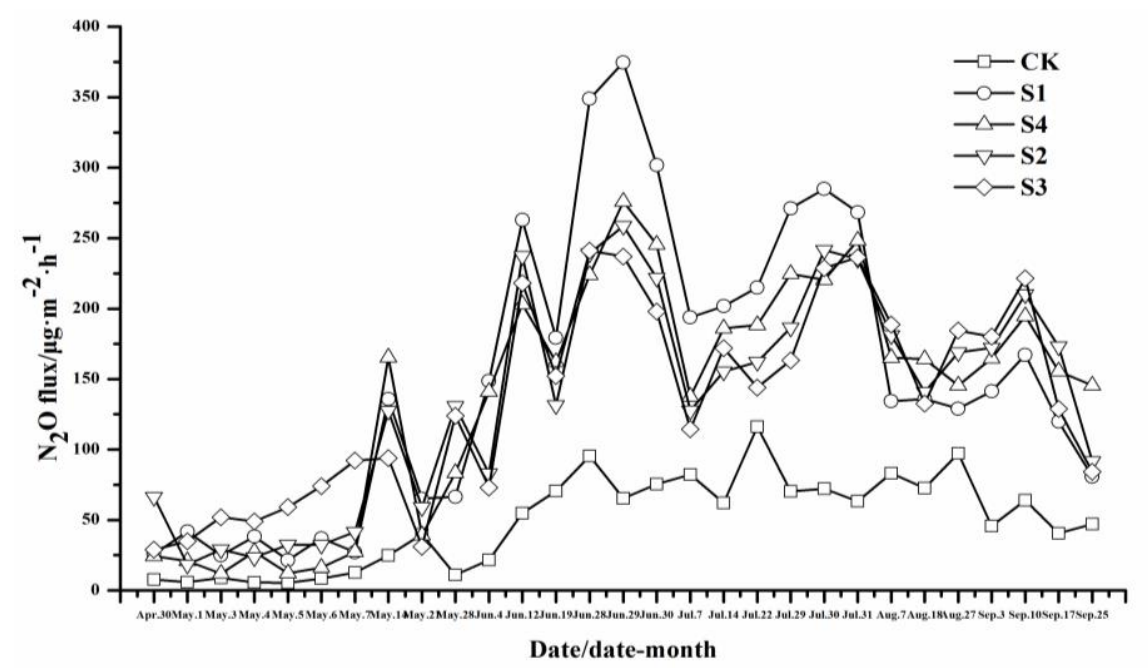

Figure 4. Emission flux of $\mathrm{N}_{2} \mathrm{O}$ under conditions of agricultural waste returned to the field

\section{Effects of Agricultural Waste on the Dynamic Change Characteristics of $\mathrm{CH}_{4}$ Emissions}

The $\mathrm{CH}_{4}$ emission flux in this study is shown in Figure 5. The figure shows that each treatment presents a negative value; that is, the atmospheric $\mathrm{CH}_{4}$ was absorbed by the soil. However, the single application of chemical fertilizer (S1) treatment on August 27 and the $100 \%$ straw return (equal to the application of pure $\mathrm{N}$ at $215.62 \mathrm{~kg} \cdot \mathrm{hm}^{-2} ; \mathrm{S} 2$ ) treatment presented positive values of $15.04 \mu \mathrm{g} \cdot \mathrm{m}^{-2} \cdot \mathrm{h}^{-1}$ and $8.80 \mu \mathrm{g} \cdot \mathrm{m}^{-2} \cdot \mathrm{h}^{-1}$, respectively. This result may be due to three days of continuous rainfall that occurred from August 23 through August 25; furthermore, the cumulative rainfall of $57.00 \mathrm{~mm}$, soil moisture content, and suitable conditions for methanogens were inhibited. Similarly, the absorption of $\mathrm{CH}_{4}$ on June 12 fluctuated, which may be related to the rainfall on June 10 and June 11 . Two peaks of $117.55 \mu \mathrm{g} \cdot \mathrm{m}^{-2} \cdot \mathrm{h}^{-1}$ and $95.02 \mu \mathrm{g} \cdot \mathrm{m}^{-2} \cdot \mathrm{h}^{-1}$ 
occurred on June 29 and July 30, respectively. Under conditions of equal N, P and K, the single application of chemical fertilizer (S1) treatment presented the largest absorption of $\mathrm{CH}_{4}$ from the atmosphere, and there was no large fluctuation after the $\mathrm{S} 2$, S3 or S4 organic and inorganic fertilizer applications. As shown in Table 4, the average absorption flux and Cumulative emission flux were in the S1 treatment were significantly higher than those in the three agricultural waste treatments, the average emission flux S1 treatment absorbed 68\% more than the S2 treatment $(\mathrm{P}<0.05), 40 \%$ more than the $\mathrm{S} 3$ treatment $(\mathrm{P}<0.05)$, and $23.53 \%$ more than the $\mathrm{S} 4$ treatment $(\mathrm{P}<0.05)$, the average emission flux difference of the three kinds of agricultural waste is not significant, and comparison among these three agricultural waste treatments, cumulative emission flux were the largest in $\mathrm{S} 4,51.85 \%$ more than $\mathrm{S} 2(\mathrm{P}<0.05)$ and $17.14 \%$ more than S3 $(\mathrm{P}<0.05)$, and the differences are significant between S4 and both S2 and S3.

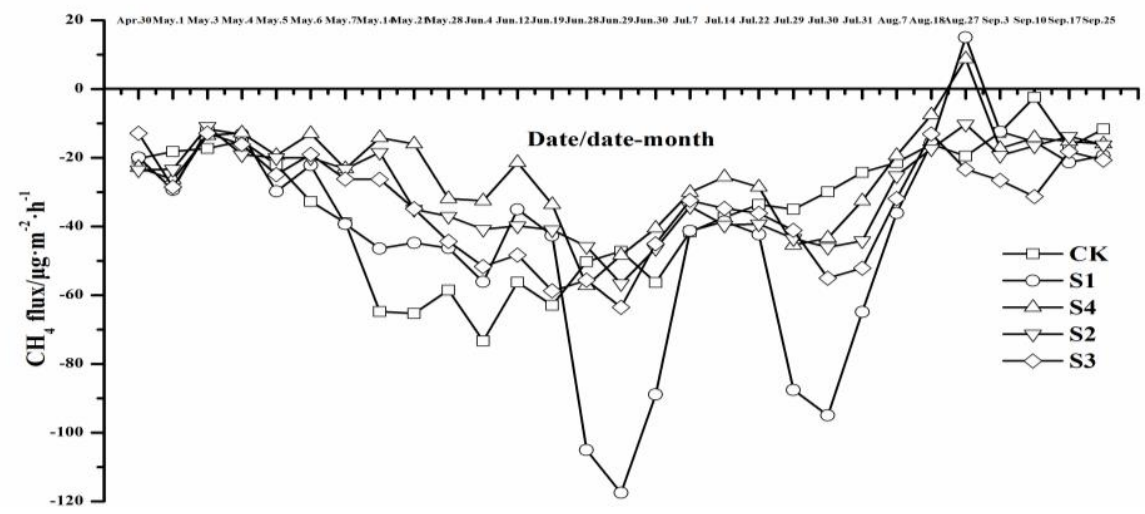

Figure 5. Emission flux of $\mathrm{CH}_{4}$ under conditions of agricultural waste returned to the field

\section{Impact of Agricultural Waste Disposal on the Global Warming Potential (GWP)}

The GWP from corn fields is derived mainly from $\mathrm{N}_{2} \mathrm{O}$ emissions, as $\mathrm{N}_{2} \mathrm{O}$ is a global greenhouse gas with a dominant warming potential. However, the offset of $\mathrm{CH}_{4}$ from the GWP of corn fields is only a very small proportion. In this experiment, the fixed $\mathrm{C}$ in the soil, which constitutes the offset ratio of the GWP within the corn field, accounts for a large proportion. As shown in Table 5, the GWP from the cutting and returning of straw to the field ( $\mathrm{S} 2$ treatment) was significantly higher than that from the other treatments. In addition, the GWP from returning cow manure to the field (S3) was lower than that from the $\mathrm{S} 1$ treatment, which significantly differed from the other treatments. The greenhouse gas emission intensity (GHGI) in the S3 treatment was significantly the lowest among all the treatments.

Table 5. Global warming potential of the different treatments

\begin{tabular}{|c|c|c|c|c|}
\hline Treatment & $\begin{array}{c}\mathrm{E}-\mathrm{CH}_{4} \\
\mathrm{CO}_{2}\left(\mathbf{k g} \cdot \mathbf{h m}^{-2}\right)\end{array}$ & $\begin{array}{c}\text { E-N2O } \\
\mathrm{CO}_{2}\left(\mathbf{k g} \cdot \mathbf{h m}^{-2}\right)\end{array}$ & $\begin{array}{c}\mathrm{GWP}\left(\mathrm{CH}_{4}+\mathrm{N}_{2} \mathrm{O}\right) \\
\mathrm{CO}_{2}\left(\mathrm{~kg}^{2} \cdot \mathrm{hm}^{-2}\right)\end{array}$ & $\begin{array}{c}\text { Emission intensity } \\
\mathrm{CO}_{2}\left(\mathrm{~kg} \cdot \mathrm{hm}^{-2}\right)\end{array}$ \\
\hline CK & $-32.925 \mathrm{a}$ & $616.86 \mathrm{e}$ & $8122.79 \mathrm{~d}$ & - \\
\hline $\mathrm{S} 1$ & $-34 \mathrm{a}$ & $1713.5 \mathrm{a}$ & $15433.8 b$ & $0.129 \mathrm{a}$ \\
\hline S2 & $-26.3 c$ & $1594.3 \mathrm{c}$ & $16430.75 \mathrm{a}$ & $0.114 b c$ \\
\hline $\mathrm{S} 3$ & $-30.775 b$ & $1552.58 \mathrm{~d}$ & $14898.4 \mathrm{c}$ & $0.111 \mathrm{c}$ \\
\hline $\mathrm{S} 4$ & $-20.2 d$ & $1641.98 \mathrm{~b}$ & $15479.09 \mathrm{~b}$ & $0.119 \mathrm{~b}$ \\
\hline
\end{tabular}

E- $\mathrm{CH}_{4}$ and $\mathrm{E}-\mathrm{N}_{2} \mathrm{O}$ are emissions of $\mathrm{CO}_{2}$ in terms of $\mathrm{CH}_{4}$ and $\mathrm{N}_{2} \mathrm{O}$, respectively

Values followed by the same letter within a column indicate no significant difference at 0.05 level 


\section{Discussion}

Applications of organic fertilizers increase source materials of $\mathrm{CO}_{2}$ production and thus promote the rate of $\mathrm{CO}_{2}$ release by soil-crop systems (Zhang et al., 2016b). A relatively high soil organic matter content promotes the growth of soil microbes, increases the bioavailability of soil $\mathrm{C}$ pools, and improves soil respiration (Xing et al., 2016). The application of organic fertilizers to agricultural soils is an effective method for increasing soil $\mathrm{C}$ pools and slowing the greenhouse effect but also increases the rate of $\mathrm{CO}_{2}$ release from soil respiration (Li et al., 2013; Yang et al., 2017). The results of the present study show that the highest peak of soil $\mathrm{CO}_{2}$ emissions in response to farmland fertilization treatment occurs on the 7th day after fertilizer application, at the jointing stage. This finding is due mainly to the combined effects of $\mathrm{N}$ topdressing fertilizers, increased rainfall after topdressing, and increased temperatures (Guo et al., 2016). Furthermore, soil $\mathrm{CO}_{2}$ emission peaks occurred after each topdressing during the corn growing season. These peaks occurred because the application of $\mathrm{N}$ fertilizer provides corn and microorganisms with $\mathrm{N}$ needed for growth; consequently, root respiration increases, and the soil temperature increases. Moreover, $\mathrm{N}$ fertilizer promoted intense activity of soil microorganisms, resulting in a rapid increase in soil $\mathrm{CO}_{2}$ flux (Afreh et al., 2018; Wang et al., 2016). The $\mathrm{CO}_{2}$ emission flux of soil treated with organic fertilizer and inorganic fertilizer was significantly higher than that treated without fertilizer (CK). This phenomenon was especially true for the $\mathrm{CO}_{2}$ emission flux from the treatment in which straw was combined with inorganic fertilizer, which is consistent with previous research results (Ping et al., 2018; Shah et al., 2016). Studies have shown that organic fertilizers have a significant impact on soil emissions. This impact occurs mainly because the application of organic fertilizers improves the physical and chemical properties of soils, increases the accumulation of soil organic matter, and promotes both the activity of soil microorganisms and the growth and vitality of the root system, thus increasing emissions (Nigussie et al., 2017). Applications of crop straw can significantly reduce the soil bulk density and can increase soil porosity, accelerating the release of $\mathrm{CO}_{2}$ gas that was generated in the soil to the atmosphere; thus, the $\mathrm{CO}_{2}$ emission flux from straw combined with inorganic fertilizer is greatest.

Soil $\mathrm{N}_{2} \mathrm{O}$ is a product of nitrification and denitrification, which are performed by microorganisms. $\mathrm{N}_{2} \mathrm{O}$ emissions from farmland are constrained by soil aeration conditions and the concentrations of the reaction substrates. The application of organic fertilizer to farmland provides exogenous $\mathrm{C}$ and $\mathrm{N}$ to the soil, which is also provided by the decomposition of organic matter. The energy required for the additional organic $\mathrm{C}$ affects the activity of soil microbes, which then affects nitrification and denitrification (Shi et al., 2017). The results of the present study show that the peak time of $\mathrm{N}_{2} \mathrm{O}$ emissions from farmland soils in each fertilization treatment is consistent with the peak $\mathrm{CO}_{2}$ emissions from the soil, both of which occurred on the 7th day after topdressing at the jointing stage. This result may be due to the rapid increase in soil $\mathrm{N}$ content caused by the $\mathrm{N}$ topdressing fertilizer. The average $\mathrm{N}_{2} \mathrm{O}$ emissions and total emissions in response to the agricultural wastes were significantly lower than those in response to single fertilizers. This result is because single fertilizers increase crop biomass and then enter soils through rice stalks, roots and other residual biomass to promote soil microbial $\mathrm{N}$ activity, which in turn increases $\mathrm{N}_{2} \mathrm{O}$ emissions. Moreover, the joint effects of increased rainfall and increased temperature during jointing may have been a factor. Guyader and Maris also concluded that the application of organic fertilizers to treat $\mathrm{N}_{2} \mathrm{O}$ 
emissions was significantly lower than that of inorganic fertilizers (Guyader et al., 2017; Maris et al., 2016). Giweta also conducted experiments on the long-term fertilization of cultivated red soil and pointed out that the combined application of chemical fertilizers and organic fertilizers could reduce $\mathrm{N}_{2} \mathrm{O}$ emissions (Giweta et al., 2017). The substitution of organic fertilizers for chemical fertilizers (at equal $\mathrm{N}$ concentrations) can effectively reduce $\mathrm{N}_{2} \mathrm{O}$ emissions from dryland fields (Nótás, 2014). Some previous studies have shown that the application of straw and cow manure can increase soil organic matter content, consume soil $\mathrm{O}_{2}$ concentration, form anaerobic environment, and promote denitrification and increase $\mathrm{N}_{2} \mathrm{O}$ emissions (Liu et al., 2008; Lu et al., 2011). However, the results of this study did not significantly increase $\mathrm{N}_{2} \mathrm{O}$ emissions, probably due to the application of high $\mathrm{C} / \mathrm{N}$ organic materials, stimulating soil heterotrophic microbial growth and reproduction, fixing free $\mathrm{NH}^{4+}-\mathrm{N}$ in the soil, thereby inhibiting the activity of nitrifying microorganisms in the soil, thus failing to promote $\mathrm{N}_{2} \mathrm{O}$ emissions (Recous et al., 1990).

In soils, $\mathrm{CH}_{4}$ is released mainly by anaerobic methanogens during the process of transmission to the atmosphere, and only a portion of the $\mathrm{CH}_{4}$ enters the atmosphere (Bansal et al., 2018). Some studies have reported that dryland soils have low $\mathrm{CH}_{4}$ emissions and that there are many external factors, and dryland soils exhibit good permeability and do not easily produce anaerobic environments; the soil organic matter decomposition rate is high, and soil organic $\mathrm{C}$ does not easily accumulate and thus affects $\mathrm{CH}_{4}$ production. Emissions are therefore considered an important sink of atmospheric $\mathrm{CH}_{4}$ (Veretennikovn et al., 2017). Gao showed that dry soils with good permeability could inhibit the activity of methanogens and lead to lower $\mathrm{CH}_{4}$ emissions (Gao et al., 2015). The results of the present study showed that, under conditions of equal nutrient concentrations, the characteristics of the different treatments affected the overall absorption and emissions of $\mathrm{CH}_{4}$; that is, dryland soil serves as an important sink of atmospheric $\mathrm{CH}_{4}$, and the single fertilizer treatment and straw return treatment presented emissions on August 27, which may be due to the continuous rainfall that occurred from August 23-25. On the 3rd day of rainfall, the soil moisture content increased, making the conditions suitable for methanogens. In this study, the $\mathrm{CH}_{4}$ emission flux observed under different fertilization treatments has both positive and negative values, and other soils from the cultivated land or grassland (Omonode et al., 2007; Shimizu et al., 2007). The results of this study are consistent. The cumulative emissions during the entire growth period are negative, indicating that soil is the net absorption sink of $\mathrm{CH}_{4}$. However, some researchers have concluded that the application of organic fertilizers or organic and inorganic fertilizers combined with the application of $\mathrm{CH}_{4}$ absorption in dry soil (Dong et al., 2005; Yang et al., 2010). In the dryland fields, the effects of the applications of chemical fertilizers and organic fertilizers to soils on the absorption of $\mathrm{CH}_{4}$ are not consistent, and additional research is needed.

Understanding the contribution of a specific agricultural measure to the greenhouse effect should help in calculating the effects of that measure in combination with others. Due to the different warming effects of the three greenhouse gases, $\mathrm{CO}_{2}, \mathrm{CH}_{4}$, and $\mathrm{N}_{2} \mathrm{O}$, their impact on global warming is also different. In this paper, the GWP is used to represent the combined effect of the three types of greenhouse gases, that is, to evaluate their comprehensive contribution by calculating the amount of $\mathrm{CO}_{2}$ emissions equivalent to the cumulative amount of greenhouse gases emitted from the soil (Lin et al., 2016). From the data obtained from this experiment, the calculated GWP of the treatment in which straw was returned to the field was significantly higher than that of 
the other treatments, and the lowest GWP was in the treatment in which cattle manure was returned. However, to evaluate the comprehensive greenhouse effects of an agricultural ecosystem, not only must the equivalent $\mathrm{CO}_{2}$ emissions from greenhouse gas emissions be calculated but also the $\mathrm{CO}_{2}$ emissions caused by agricultural activities, such as irrigation, machinery and fertilizer applications, must be considered (Song et al., 2013; Sainju et al., 2016). Regarding the three types of agricultural waste treatments in this paper, the soil $\mathrm{C}$ sequestration potential and the contribution of different ratios to the greenhouse effect must be further studied.

\section{Conclusion}

The results of this study show that the average $\mathrm{CO}_{2}$ flux and total discharge of the straw return treatment were the highest, reaching $388.96 \mathrm{mg} \cdot \mathrm{m}^{-2} \cdot \mathrm{h}^{-1}$ and 14718.97 $\mathrm{kg} \cdot \mathrm{hm}^{-2}$, respectively, and the $\mathrm{N}$ topdressing fertilizer effects were obvious. With respect to $\mathrm{CH}_{4}$ emissions, the single fertilizer treatment presented the greatest average absorbed flux and total absorbed amount, which were $0.042 \mathrm{mg} \cdot \mathrm{m}^{-2} \cdot \mathrm{h}^{-1}$ and $1.36 \mathrm{~kg} \cdot \mathrm{hm}^{-}$ ${ }^{2}$, respectively, and with respect to $\mathrm{N}_{2} \mathrm{O}$ fluxes, the highest flux and amount were 0.153 $\mathrm{mg} \cdot \mathrm{m}^{-2} \cdot \mathrm{h}^{-1}$ and $5.75 \mathrm{~kg} \cdot \mathrm{hm}^{-2}$, respectively. The GWP and GHGI of the straw return treatment were significantly higher than those of the other treatments, and the GWP and GHGI of the cattle manure return treatment were significantly lower than those of the other treatments. On the basis of the comprehensive greenhouse effect of the soils and GHGI, it was determined that, compared with the application of chemical fertilizers, the application of the combination of organic and inorganic fertilizers not only reduced the soil's comprehensive greenhouse effect (GWP) but also reduced the GHGI of the soil. Therefore, to achieve increased corn yields and to reduce the GHGI concurrently, the combination of organic and inorganic fertilizer applications (especially those comprising cow manure) represents an ideal soil fertility method in the black soil region of Northeast China.

Acknowledgements. This research was supported by the National Key R\&D Program of China (2018YFD030020-3, 2017YFD0300604-2 and 2017YFC0504200); National Natural Science Foundation of China (41430857); Key Research Program of Frontier Sciences, Chinese Academy of Sciences (Grant No. QYZDB-SSW-DQC035); Youth Innovation Promotion Association, Chinese Academy of Sciences (2015183); and "135" project planning of Northeast Institute of Geography and Agroecology, Chinese Academy of Sciences (Y6H2042001).

\section{REFERENCES}

[1] Afreh, D., Zhang, J., Guan, D., Liu, K., Song, Z., Zheng, C. (2018): Long-term fertilization on nitrogen use efficiency and greenhouse gas emissions in a double maize cropping system in subtropical China. - Soil \& Tillage Research 180: 259-267.

[2] Bansal, S., Tangen, B., Finocchiaro, R. (2018): Diurnal patterns of methane flux from a seasonal wetland: mechanisms and methodology. - Wetlands: 1-11.

[3] Cheng, G., Zhang, A. F., Wang, X. D., Zhang, W. H., Ke-Qing, D. U. (2016): Assessment of wheat straw and its biochar effects on carbon sink in agricultural ecosystems using "carbon footprint" method. - Journal of Agro-Environment Science 35(3): 604-612. 
[4] Ding, M. J., Huang, Y., Yi, W. J., Liu, Y., Chen, Z. S. (2016): Effects of applying organic manure on nitrogen transformation and functional microbes of tobacco-planting soil. Southwest China Journal of Agricultural Sciences 29(5): 1166-1171.

[5] Dong, Y. H., Ouyang, Z. ( 2005): Effects of organic manures on CO2 and CH4 fluxes of farmland. - Chinese Journal of Applied Ecology 16(7): 1303-1307.

[6] Epps, A. V., Blaney, L. (2016): Antibiotic residues in animal waste: occurrence and degradation in conventional agricultural waste management practices. - Current Pollution Reports 2(3): 1-21.

[7] Gao, D. C., Zhang, L., Liu, Q. (2015): Effects of biochar on CO2, CH4, N2O emission and its environmental benefits indryland soil. - Acta Ecologica Sinica 35(11): 3615-3624.

[8] Ge, Q. S., Wang, F., Wang, S. W., Cheng, B. B. (2014): Certainty and Uncertainty in Global Warming Studies. - China Population, Resources and Environment 24(1): 1-5.

[9] Giweta, M., Dyck, M. F., Malhi, S. S. (2017): Growing season nitrous oxide emissions from a gray luvisol as a function of long-term fertilization history and crop rotation. Canadian Journal of Soil Science 97(3): 474-486.

[10] Guo, T. F., Liang, G. Q., Zhou, W., Liu, D. H., Wang, X. B., Sun, J. W. (2016): Effect of fertilizer management on greenhouse gas emission and nutrient status in paddy soil. Journal of Plant Nutrition \& Fertilizer 22(2): 337-345.

[11] Guyader, J., Little, S., Kröbel, R., Benchaar, C., Beauchemin, K. A. (2017): Comparison of greenhouse gas emissions from corn- and barley-based dairy production systems in eastern canada. - Agricultural Systems 152: 38-46.

[12] IPPC (Intergovernmental Panel on Climate Change) (2013): Climate change 2013-The physical science basis. - Working group I contribution to the fifth assessment report of the IPCC. Cambridge, UK: Cambridge University Press.

[13] Kröbel, R., Bolinder, M. A., Janzen, H. H., Little, S. M., Vandenbygaart, A. J., Kätterer, T. (2016): Canadian farm-level soil carbon change assessment by merging the greenhouse gas model holos with the introductory carbon balance model (icbm). - Agricultural Systems 143: 76-85.

[14] Li, B., Rong, X. M., Xie, G. X., Zhang, Y. P., Zhou, L., Zhang, Y. (2013): Effect of combined application of organic and inorganic fertilizers on greenhouse gases exchange and comprehensive global warming potential in paddy fields. - Journal of Soil \& Water Conservation 27(6): 298-304.

[15] Liang, A. Z., Yang, X. M., Zhang, X. P. (2016): Changes in soil organic carbon stocks under 10-year conservation tillage on a Black soil in Northeast China. - The Journal of Agricultural Science 154(8): 1425-1436.

[16] Lin, L., Gettelman, A., Fu, Q., Xu, Y. (2016): Simulated differences in 21st century aridity due to different scenarios of greenhouse gases and aerosols. - Climatic Change: 116.

[17] Liu, E. K., Zhao, B. Q., Li, X. Y. (2008): Biological properties and enzymatic activity of arable soils affecten by long-term different fertilization system. - Journal of Plant Ecology (Chinese Version) 32(1): 176-182.

[18] Lozano, F. J., Lozano, R. (2017): Assessing the potential sustainability benefits of agricultural residues: Biomass conversion to syngas for energy generation or to chemicals production. - Journal of Cleaner Production 172: 4162-4169.

[19] Lu, W. T., Jia, Z. K., Zhang, P., Wang, W. (2011): Effects of straw returning on soil labile organic carbon and enzyme activity in semi-arid areas of Southern Ningxia, China. - Journal of Agro-Environment Science 30(3): 522-528.

[20] Maris, S. C., Teira-Esmatges, M. R., Bosch-Serra, A. D., Moreno-García, B., Català, M. M. (2016): Effect of fertilising with pig slurry and chicken manure on ghg emissions from mediterranean paddies. - Science of the Total Environment: 569-570.

[21] Mitran, T., Mani, P. K., Basak, N., Mazumder, D., Roy, M. (2016): Long-term manuring and fertilization influence soil inorganic phosphorus transformation visavis rice yield in a riceâ wheat cropping system. - Archives of Agronomy \& Soil Science 62(1): 1-18. 
[22] National Development and Reform Commission (2013): Second National Communication on Climate Change of The People's Republic of China. - Department of Climate Change, Beijing: China Economic Press: 15-20.

[23] Nigussie, A., Bruun, S., Kuyper, T. W., De, N. A. (2017): Delayed addition of nitrogenrich substrates during composting of municipal waste: effects on nitrogen loss, greenhouse gas emissions and compost stability. - Chemosphere 166: 352-362.

[24] Nótás, E. (2014): Effect of $\mathrm{N}$ fertilizer forms and soil moisture levels on then gaseous losses. - Applied Ecology and Environmental Research 12(2): 589-599.

[25] Omonode, R. A., Vyn, T. J., Smith, D. R., Hegymegi, P. (2007): Soil carbon dioxide and methane fluxes from long-term tillage systems in continuous corn and corn-soybean rotation. - Soil \& Tillage Research 95: 182-195.

[26] Ping, L. I., Lang, M., Miao, L. I., Wei, W., Kai-Kai, L. I. (2018): Short-term effects of different fertilization treatments on greenhouse gas emissions from northeast black soil. Environmental Science 22(2): 337-345.

[27] Qin, Z., Dunn, J. B., Kwon, H., Mueller, S., Wander, M. M. (2016): Influence of spatially dependent, modeled soil carbon emission factors on life-cycle greenhouse gas emissions of corn and cellulosic ethanol. - Global Change Biology Bioenergy 8(6): 1136-1149.

[28] Recous, S., Mary, B., Faurie, G. (1990): Microbial immobilization of ammonium and nitrate in cultivated soils. - Soil Biology and Biochemistry 22(7): 913-922.

[29] Sainju, U. M. (2016): A global meta-analysis on the impact of management practices on net global warming potential and greenhouse gas intensity from cropland soils. - Plos One 11(2): e0148527.

[30] Salehi, A., Fallah, S., Sourki, A. A. (2017): Organic and inorganic fertilizer effect on soil $\mathrm{CO} 2$ flux, microbial biomass, and growth of nigella sativa 1. - International Agrophysics 31(1): 103-116.

[31] Shah, A., Lamers, M., Streck, T. (2016): N2O and CO2, emissions from south german arable soil after amendment of manures and composts. - Environmental Earth Sciences 75(5): 1-12.

[32] Shi, X., Hu, H. W., Zhubarker, X., Hayden, H., Wang, J., Suter, H. (2017): Nitrifierinduced denitrification is an important source of soil nitrous oxide and can be inhibited by a nitrification inhibitor 3,4-dimethylpyrazole phosphate (dmpp). - Environmental Microbiology 19(12): 27-33.

[33] Shimizu, M., Hatano, R., Arita, T., Kouda, Y., Mori, A. (2013): The effect of fertilizer and manure application on $\mathrm{CH} 4$ and $\mathrm{N} 2 \mathrm{O}$ emissions from managed grassland in Japan. Soil Science and Plant Nutrition 59: 69-86.

[34] Song, L. N., Zhang, Y. M., Hu, C. S. (2013): Comprehensive analysis of emissions and global warming effects of greenhouse gases in winter-wheat fields in the high-yield agroregion of North China Plain. - Chinese Journal of Eco-Agriculture 21(3): 297-307.

[35] Veretennikova, E. E., Dyukarev, E. A. (2017): Diurnal variations in methane emissions from west siberia peatlands in summer. - Russian Meteorology \& Hydrology 42(5): 319326.

[36] Wang, Z. B., Chen, J., Mao, S. C., Han, Y. C., Chen, F., Zhang, L. F. (2016): Comparison of greenhouse gas emissions of chemical fertilizer types in china's crop production. Journal of Cleaner Production 141: 1267-1274.

[37] Xing, P. F., Xiao-Sen, W. U., Gao, S. C., Hong-Jie, L. I., Zhao, T. K., Zhou, X. L. (2016): Effects of different fertilization on soil microbial community and functional diversity in maize-wheat crop rotation. - Journal of Microbiology 36(1): 22-29.

[38] Xu, Y. P., Zhu, H. J., Cheng, X. W., Ji, J. (2018): Study on the evolution of agricultural waste recycling industry and multi-industry linkage. - Journal of Chinese Agriculture Mechanization 39(4): 90-94.

[39] Yang, Q. B., Fan, F. L., Wang, W. X. (2010): Effects ofdifferent long -term fertilizations on community properties and functions of methanotrophs in dark brown soil. Environmental Science 31(11): 2756-2762. 
[40] Yang, M., Li, Y., Li, Y., Chang, S. X., Yue, T., Fu, W. (2017): Effects of inorganic and organic fertilizers on soil $\mathrm{CO} 2$ efflux and labile organic carbon pools in an intensively managed moso bamboo (phyllostachys pubescens) plantation in subtropical China. Communications in Soil Science \& Plant Analysis 48(3): 332-344.

[41] Yuan, J., Sha, Z. M., Hassani, D., Zhao, Z., Cao, L. K. (2017): Assessing environmental impacts of organic and inorganic fertilizer on daily and seasonal greenhouse gases effluxes in rice field. - Atmospheric Environment 155: 119-128.

[42] Yue, W., Dong, H., Zhu, Z., Gerber, P. J., Xin, H., Smith, P. (2017): Mitigating greenhouse gas and ammonia emissions from swine manure management: a system analysis. - Environmental Science \& Technology 51(8): 4503-4511.

[43] Zhang, Y. S., Chai, R. S., Fu, L. L. (2012): Greenhouse gas emissions from major agricultural activities in China and corresponding mitigation strategies. - Journal of Zhejiang University (Agriculture and Life Sciences) 38(1): 97-107.

[44] Zhang, Z. S., Cao, C. G., Guo, L. J., Li, C. F. (2016a): Emissions of CH4, and CO2, from paddy fields as affected by tillage practices and crop residues in central china. - Paddy \& Water Environment 14(1): 85-92.

[45] Zhang, J., Zhang, J., Shen, G., Wang, R., Gao, L., Li, Z., Dai, Y., Meng, G., Xiang, B., Zhang, Z. (2016b): Effects of different types of straw and stalk returning on carbon and nitrogen mineralization in tobacco soil. - Tobacco Science \& Technology 49(2): 1-6.

[46] Zhang, K., Zheng, H., Chen, F., Li, R., Yang, M., Ouyang, Z. (2017): Impact of nitrogen fertilization on soil-atmosphere greenhouse gas exchanges in eucalypt plantations with different soil characteristics in southern china. - Plos One 12(2): e0172142.

[47] Zhao, J., Li, Y., Ran, W. (2016): Effects of organic manure partial substitution for chemical fertilizer on crop yield and soil microbiome in a rice-wheat cropping system. Journal of Nanjing Agricultural University 39(4): 594-602. 